\title{
Effects of freezing temperature on the physiological activities of garlic extracts
}

\author{
Jong Woo Park ${ }^{1 *}$, Jinse Kim ${ }^{1}$, Seok Ho Park ${ }^{1}$, Dong Soo Choi ${ }^{1}$, Seung Ryul Choi ${ }^{1}$, \\ Sungsik $\mathrm{Oh}^{1}$, Yong Hoon $\mathrm{Kim}^{1}$, Seon Mi Yoo ${ }^{2}$, Gui Jeung $\mathrm{Han}^{2}$ \\ ${ }^{1}$ Division of Postharvest Engineering, National Academy of Agricultural Science, RDA, Wanju 55365, Korea \\ ${ }^{2}$ Division of Agro-Food Utilization, National Academy of Agricultural Science, RDA, Wanju 55365, Korea
}

\section{냉동 온도에 따른 마늘 추출물의 생리활성 변화}

\author{
박종우 $^{1 *} \cdot$ 김진세 $^{1} \cdot$ 박석호 $^{1} \cdot$ 최동수 $^{1} \cdot$ 최승렬 $^{1} \cdot$ 오성식 $^{1} \cdot$ 김용훈 $^{1} \cdot$ 유선미 $^{2} \cdot$ 한귀정 $^{2}$ \\ ${ }^{1}$ 농촌진흥청 국립농업과학원 수확후관리공학과 \\ ${ }^{2}$ 농촌진흥청 국립농업과학원 가공이용과
}

\begin{abstract}
This study investigated the physiological activities of garlic extracts frozen at $-\mathbf{2 0},-\mathbf{8 0}$, and $-196^{\circ} \mathrm{C}$. To determine the optimum freezing temperature for maintaining garlic's physiological activity, antioxidant and antibacterial activities were investigated. The antioxidant activities were determined by DPPH radical scavenging ability, SOD-like activity, nitrite-scavenging ability, and reducing power. Total phenolic compounds and flavonoids of garlic extract frozen at $4^{\circ} \mathrm{C}$ (control) were measured as $6.91 \pm 0.69 \mu \mathrm{g} \mathrm{GAE} / \mathrm{g}$ and $0.315 \pm 0.017 \mu \mathrm{g} \mathrm{QE} / \mathrm{g}$, respectively. Although the content of total phenolic compounds was not affected by the different freezing temperatures, the flavonoids contents of garlic extract frozen at $-20^{\circ} \mathrm{C}$ were slightly decreased. The DPPH radical scavenging ability of garlic extracts $\left(2 \mathrm{mg} / \mathrm{mL}\right.$ ) frozen at $-80^{\circ} \mathrm{C}$ was $61 \%$, whereas those frozen at $-20^{\circ} \mathrm{C}$ and $-196^{\circ} \mathrm{C}$ were $51 \%$. SOD-like activity was slightly increased by freezing. However, the nitrite scavenging ability $(18 \%$ at $\mathrm{pH} 3.0)$ and reducing power $(O D 700=1.6)$ were not affected by freezing temperatures. Antimicrobial activities did not show significant differences depending on freezing temperatures. Taken together, the physiological activities of the frozen garlic extracts were not significantly changed by the freezing temperatures; however, the antioxidant and antibacterial effects of the phenolic compounds and flavonoids were maintained at $-80^{\circ} \mathrm{C}$. These results suggest that $-80^{\circ} \mathrm{C}$ frozen garlic could maintain a higher quality than the conventional freezing method $\left(-20^{\circ} \mathrm{C}\right)$ without loss of physiological activities during the storage.
\end{abstract}

Key words : garlic, physiological activity, freezing temperature, antioxidant, antibacterial

\section{서 론}

마늘(Allium sativum L.)은 대표적인 백합과 파속의 다년 초 식물로서 국내 채소류 중 고추, 양파, 파, 생강과 더불어 대표적인 조미채소로 분류된다. 통계청의 채소생산량 지표

*Corresponding author. E-mail : jwpark0824@chosun.kr Phone : 82-63-238-4124, Fax : 82-63-238-4105

Received 10 July 2015; Revised 6 August 2015; Accepted 11 August 2015.

Copyright (c) The Korean Society of Food Preservation. All rights reserved.
에 따르면 최근 5년간 국내 마늘생산량은 년 평균 334,337 톤으로 전체 조미채소 생산량( $2,345,211$ 톤)의 $14.3 \%$ 를 차 지하고 있으나 최근 마늘생산량이 차지하는 비중은 2010년 $11.1 \%$ 에서 2015년 $17.4 \%$ 로 지속적인 증가추세를 나타내고 있다. 이러한 조미채소 중 마늘이 차지하는 비중의 증가는 근래에 들어 마늘의 항산화(1-3), 항균(4,5), 항혈전(6) 및 콜레스테롤 저하 $(7,8)$ 를 통한 혈액순환 개선효과와 같은 다양한 생리활성 효과가 과학적으로 입증되면서 다양한 형태로 소비가 늘어남에 따라 마늘의 재배면적 및 생산량 증가 추세를 나타내는 것으로 볼 수 있다.

우리나라에서 재배되는 마늘은 기후특성에 따라 비교적 
제주, 남해, 해남, 무안 등지에서 재배되는 난지형 마늘과 의성, 서산, 삼척 등지에서 재배되는 한지형 마늘로 구분되 며, 한지형 마늘의 경우 대부분 6쪽 내외로 맵고 저장성이 좋은 반면 난지형 마늘은 쪽수가 불규칙하고 매운맛이 약하 고 저장성이 낮은 특징을 가진다. 일반적인 난지형 마늘의 주요 저장방법은 예건 후 $0 \sim-2{ }^{\circ} \mathrm{C}$ 에서의 저온 및 controlled atmosphere(CA) 저장을 통해 맹아신장을 억제하여 저장 8 개월까지 상품성을 유지할 수 있다고 알려져 있다(9). 하지 만 저온저장법의 경우 갈변 및 청변 현상이 빈번하게 발생 하고 $\mathrm{CA}$ 저장의 경우에는 저장효과는 우수하나 건설 및 유지비용이 합리적이지 못하여 사용에 어려움이 있어 마늘 의 새로운 저장 및 유통방법에 대한 논의가 지속적으로 이루어지고 있다(10). 이에 따라 최근 늘어나는 마늘의 생산 량과 소비에 따른 수급조절을 위해 냉동저장이 고려되고 있으며, 원물 저장 및 품질변화를 고려한 다진 마늘의 개별 포장 냉동에 관심이 모아지고 있다(11). 뿐만 아니라 냉동품 질 개선을 위한 농산물 급속냉동기술에 대한 연구가 활발히 진행 중이다 $(12,13)$.

현재까지의 냉동저장에 따른 마늘의 품질변화에 대한 연구는 Shin 등(11)에 의한 연구가 있을 뿐 냉동저장을 위한 동결과정 및 보관에 따른 다양한 생리활성효능 변화에 대한 검토가 없었었다. 또한 저장 및 가공에서의 생리활성에 대 한 연구는 열처리 및 고온고압처리에 의한 생리활성 변화 $(14,15)$ 와 Chang 등(16)의 건조에 따른 생리활성 변화에 대한 연구가 이루어진 반면 냉동이 마늘의 생리활성효능에 미치는 영향에 대한 연구는 찾아보기 어려운 실정이다. 따라서 본 연구에서는 마늘의 냉동 저장을 위한 냉동온 도에 따른 마늘의 생리활성효능의 변화를 분석하고 최적의 냉동 온도를 선정하고자 하였다.

\section{재료 및 방법}

\section{실험재료}

본 실험에 사용된 마늘은 난지형 마늘로 고흥에서 2015 년도에 수확된 마늘을 도매상을 통해 구입 후 수작업으로 상처가 나지 않게 껍질을 제거하였다. 외관이 양호한 것을 선별하였고 이때 마늘의 수분함량은 68 70\%이었다.

\section{마늘의 냉동 및 추출물의 제조}

냉동조건에 따른 마늘 추출물을 준비하기 위하여 마늘을 비냉동 $\left(4^{\circ} \mathrm{C}\right)$, 관행냉동 $\left(-20^{\circ} \mathrm{C}\right)$, 급속냉동 $\left(-80^{\circ} \mathrm{C}\right)$, 그리고 초 저온 냉동 $\left(-196^{\circ} \mathrm{C}\right)$ 의 4 가지 조건에서 냉동하였고, 인편 중 량이 약 $5 \mathrm{~g}$ 인 마늘을 밀폐용기에 넣고 용기 내부와 마늘의 중심부 온도변화를 온도센서(ALMEMO 2290-8, Ahlborn, Holzkirchen, Germany)를 이용하여 측정하였다. 추출물의 제조는 깐마늘 $30 \mathrm{~g}$ 을 칭량 후 밀폐용기에 넣어 각 처리
조건별로 냉동 및 저장 후, 해동 간 품질변화를 최소화하기 위하여 냉동 상태서 차가운 증류수 $60 \mathrm{~mL}$ 가하여 완전히 마쇄하고 $4,000 \mathrm{rpm}$ 으로 $4^{\circ} \mathrm{C}$ 에서 20 분간 원심분리 하여 상등액 만을 얻었다. 이렇게 얻어진 착즙액은 $0.45 \mathrm{\mu m}$ 필터 를 이용하여 여과 후 $100 \%$ 추출액으로 생리활성 분석을 위한 실험에 사용하였다. 여과된 추출액 일부를 상압가열 건조법을 이용하여 조성분의 농도를 측정한 결과 각 실험군 은 $83 \pm 2.6 \mathrm{mg} / \mathrm{mL}$ 로 일정하게 균질화가 이루어진 것을 확인 하였다.

\section{총 페놀 화합물의 함량 측정}

마늘 추출액의 총 페놀화합물 함량은 Folin-Denis(17)법 을 이용하여 페놀화합물이 phosphomolybic acid와 반응하 여 발색되는 현상을 이용하였다. 증류수 $1.6 \mathrm{~mL}$ 에 $100 \%$ 마늘 추출액 $0.1 \mathrm{~mL}, 20 \% \mathrm{Na}_{2} \mathrm{CO}_{3}$ 용액 $0.2 \mathrm{~mL}$, Folin-Denis 용액(Sigma Co., St. Louis, Mo, USA) $0.1 \mathrm{~mL}$ 을 넣고 실온에 서 30 분간 반응시킨 후 분광광도계(OPRON-3000, Hanson Tech. Co., Ltd., Seoul, Korea)를 이용하여 $700 \mathrm{~nm}$ 의 흡광도 를 측정하였다. 총 페놀 화합물의 함량은 gallic acid(Sigma Co.)를 이용한 표준 검량곡선으로부터 환산하여 마늘추출 물의 건량 $1 \mathrm{~g}$ 당 $\mu \mathrm{g}$ gallic acid equivalents(GAE), 즉 $\mu \mathrm{g}$ $\mathrm{GAE} / \mathrm{g}$ 으로 나타내었다.

\section{플라보노이드 함량 측정}

마늘 추출액의 플라보노이드 함량은 Jia 등(18)의 방법에 따라 측정하였다. 마늘 추출액 $0.2 \mathrm{~mL}$ 에 증류수 $0.8 \mathrm{~mL}$ 을 넣어 희석하고 $5 \% \mathrm{NaNO}_{2}$ (Sigma Co.) $0.1 \mathrm{~mL}$ 을 넣어 실온 에서 5 분간 반응 후 $10 \% \mathrm{AlCl}_{3}$ (Sigma Co.) $0.1 \mathrm{~mL}$ 을 넣고 6 분간 다시 방치한 다음 $1 \mathrm{M} \mathrm{NaOH(Duksan} \mathrm{Co.,} \mathrm{Ansan,}$ Korea) $0.67 \mathrm{~mL}$ 을 첨가하고 증류수를 $1.1 \mathrm{~mL}$ 을 추가하여 잘 혼합 후 $510 \mathrm{~nm}$ 의 흡광도를 측정하였다. 표준물질로는 quercetin(Sigma Co.)을 이용하여 검량곡선을 작성한 다음 플라보노이드 함량을 구하여 마늘 추출물의 건량 $1 \mathrm{~g}$ 당 $\mu \mathrm{g}$ quercetin equivalents $(\mathrm{QE})$, 즉 $\mu \mathrm{g} \mathrm{QE} / \mathrm{g}$ 으로 나타내었다.

\section{DPPH radical 소거능 측정}

마늘 추출액의 라디칼 소거능은 Blois(19)의 방법을 변형 하여 1,1-diphenyl-2-picrylhydrazyl(DPPH)에 대한 환원력으 로 측정하였다. 농도별로 희석한 마늘 추출액 $0.4 \mathrm{~mL}$ 에 $100 \mathrm{mM}$ Tris-HCl(pH 7.5) $0.6 \mathrm{~mL}, 0.2 \mathrm{mM} \mathrm{DPPH}$ 용액(Sigma Co.) $1 \mathrm{~mL}$ 을 넣고 실온에서 60 분간 반응시킨 후 $4,000 \mathrm{rpm}$ 에서 10 분간 원심분리 하여 침전물을 제거 후 $520 \mathrm{~nm}$ 의 흡광도를 측정하였다. 라디칼 소거능은 마늘 추출물 첨가 구와 무첨가구의 흡광도를 백분율로 나타내었다.

\section{SOD 유사활성 측정}

Marklund와 Marklund(20)의 방법을 이용하여 pyrogallol 
로부터 생성되는 활성 산소로부터 과산화수소로 전환시키 는 반응을 산화된 pyrogallol을 측정하여 superoxide dismutase(SOD) 유사활성으로 나타내었다. 농도 별로 희석 한 마늘 추출액 $0.4 \mathrm{~mL}$ 에 $\mathrm{pH} 8.5$ 로 보정한 Tris- $\mathrm{HCl}$ buffer(100 mM Tris containing $10 \mathrm{mM}$ EDTA) $2.8 \mathrm{~mL}, 7.2$ $\mathrm{mM}$ pyrogallol(Sigma Co.) $0.2 \mathrm{~mL}$ 을 넣고 실온에서 20 분간 반응시키고 $1 \mathrm{~N} \mathrm{HCl(Duksan} \mathrm{Co.)} 1 \mathrm{~mL}$ 을 첨가하여 반응을 정지시킨 후 $420 \mathrm{~nm}$ 의 흡광도를 측정하였다. SOD 유사활 성은 마늘 추출물의 첨가구와 무첨가구 사이의 흡광도 차이 를 백분율로 나타내었다.

\section{아질산염 소거능 측정}

아질산염 소거능은 Kato 등(21)의 방법을 이용하여 측정 하였다. 마늘 추출액 $0.125 \mathrm{~mL}$ 에 $1 \mathrm{mM} \mathrm{NaNO}_{2}$ (Sigma Co.) 용액 $0.25 \mathrm{~mL}$ 을 넣고 $0.1 \mathrm{~N} \mathrm{HCl}(\mathrm{pH} 1.2)$ 과 $0.2 \mathrm{M}$ citric $\operatorname{acid}(\mathrm{pH} 3.0$ and 6.0)를 각각 $0.875 \mathrm{~mL}$ 씩 첨가하여 반응액의 $\mathrm{pH}$ 를 $1.2,3.0$ 및 6.0 으로 보정한 후 $37^{\circ} \mathrm{C}$ 에서 1 시간 동안 반응시켰다. 반응액 $0.5 \mathrm{~mL}$ 을 취한 후 $2 \%$ acetic acid를 $1 \mathrm{~mL}$ 첨가하고, Griess reagent(A:B=1:1, A: $1 \%$ sulfanilic acid in $30 \%$ acetic acid, B: $1 \%$ naphthylamine in $30 \%$ acetic acid)를 $0.2 \mathrm{~mL}$ 첨가하여 잘 혼합한 후 실온에서 15 분간 반응시켜 $520 \mathrm{~nm}$ 의 흡광도를 측정하였다. 아질산염 소거능 은 [1-(시료 첨가구 흡광도무첨가구 흡광도)] $\times 100$ 으로 나 타내었다.

\section{Reducing power 측정}

마늘 추출물의 환원력 측정은 Oyaizu (22)의 방법을 이용 하여 측정하였다. 마늘 추출액 $0.2 \mathrm{~mL}$ 과 증류수 $0.8 \mathrm{~mL}$ 에 $200 \mathrm{mM}$ sodium phosphate(pH 6.6) $0.25 \mathrm{~mL}$ 및 $1 \%$ potassium hexacyanoferrate(III)(Sigma Co.) $0.25 \mathrm{~mL}$ 을 혼합하여 $50^{\circ} \mathrm{C}$ 에서 40 분간 반응시킨 후 $10 \%$ trichloroacetic acid(Sigma Co.) $0.5 \mathrm{~mL}$ 을 첨가하였다. 반응액을 $3,000 \mathrm{rpm}$ 에서 10 분간 원심분리하고 상등액 $1 \mathrm{~mL}$ 을 취하여 $0.1 \% \mathrm{FeCl}_{3}$ (Sigma Co.) $0.2 \mathrm{~mL}$ 을 첨가하여 혼합한 후 $700 \mathrm{~nm}$ 의 흡광도를 측정하여 absorbance unit(abs)로 나타내었다.

\section{항균활성 측정}

마늘 추출액의 항균 활성은 paper disk method를 이용하 여 측정하였다(23). 사용된 균주는 Escherichia coli ATCC 25922, Salmonella typhimurium ATCC 13311, Staphylococcus aureus ATCC 13565, Bacillus cereus ATCC 9634, Vibrio vulnificus ATCC 29307 균주를 사용하였다. 5종의 균을 생 육배지 trypticase soy broth(Difco, Sparks, $\mathrm{MD}$, USA)에 각각 접종하고 $37^{\circ} \mathrm{C}$ 에서 48 시간 배양 후 $600 \mathrm{~nm}$ 의 흡광도를 측정하여 일정한 농도로 희석된 시험균액을 준비하였다. 분석용 배지로는 Mueller-Hinton agar(Difco)와 LuriaBertani agar(Difco)를 이용하여 준비된 시험균액 $0.1 \mathrm{~mL}$ 을
도말하고, 마늘 추출액을 살균된 여과지원반 $(5 \mathrm{~mm}$, Toyo Roshi Co., Tokyo, Japan)에 $50 \mu \mathrm{L}$ 를 흡수 시킨 후 균이 도말된 배지표면에 밀착시켰다. 배지는 $37^{\circ} \mathrm{C}$ 에서 24 시간 배양한 후 여과지원반 주위에 생성된 생육저해환의 크기 $(\mathrm{mm})$ 로 항균력을 나타내었다.

\section{통계분석}

모든 분석결과는 3회 반복 실험한 결과로부터 평균값과 표준편차로 나타내었으며 통계분석은 IBM SPSS Statistics (22, IBM Corp., Armonk, NY, USA)를 이용하여 ANOVA test와 Duncan's multiple range test를 통해서 시료 간 유의적 차이 $(\mathrm{p}<0.05)$ 를 검정하였다.

\section{결과 및 고찰}

\section{온도에 따른 마늘의 냉동속도}

냉동 조건에 따른 마늘의 냉동 속도를 분석하기 위하여 각 실험군의 중심부에 온도센서를 삽입하여 각 조건에서 냉동을 수행한 결과 Fig. 1과 같았다. 관행 냉동고인 $-20^{\circ} \mathrm{C}$ 에 서 마늘은 $-5^{\circ} \mathrm{C}$ 까지 과냉각 상태를 유지하다 빙결정을 생성 하기 시작하여 $-5 \sim 0^{\circ} \mathrm{C}$ 인 최대 빙결정구간의 통과 시간이 75 분이 소요된 반면 $-80^{\circ} \mathrm{C}$ 초저온냉동고 에서는 $-3^{\circ} \mathrm{C}$ 까지 과냉각이 진행된 후 빙결정형성을 시작하여 최대 빙결정 형성구간을 8분 만에 통과하였고 액체질소를 이용한 -19 $6^{\circ} \mathrm{C}$ 냉각에서는 $-2.2^{\circ} \mathrm{C}$ 에서 빙결정형성이 이루어져 최대 빙결정 생성구간을 통과하는데 불과 1 분밖에 소요되지 않 았다. 마늘의 중심온도가 $-15^{\circ} \mathrm{C}$ 에 도달했을 때를 완전 냉동 상태로 규정했을 때 $-20^{\circ} \mathrm{C}$ 에서는 175 분, $-80^{\circ} \mathrm{C}$ 에서는 23 분, $-196^{\circ} \mathrm{C}$ 에서는 6 분이 소요되었다. 냉동에 있어서 최대 빙결

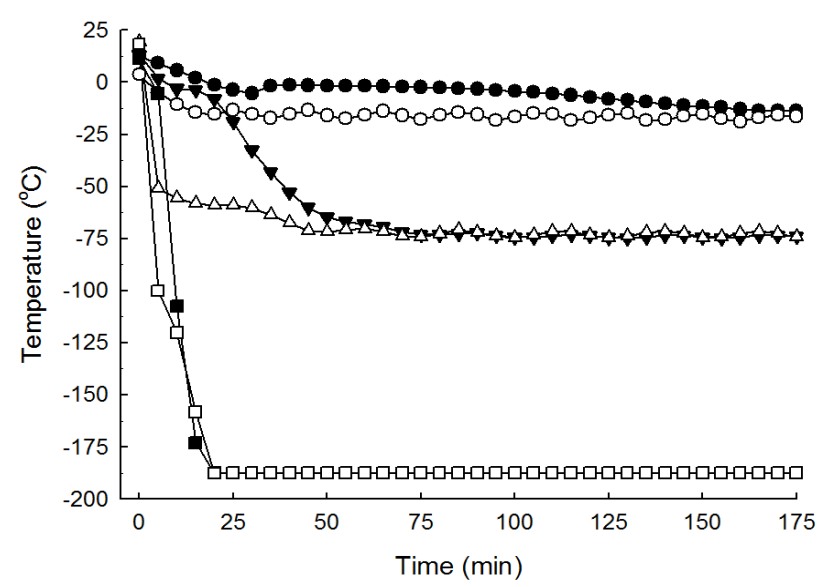

Fig. 1. Freezing curve of peeled garlics under various temperature conditions.

Data from three independent garlics were expressed as mean values. $\mathrm{O},-20^{\circ} \mathrm{C}$ container O, $-20^{\circ} \mathrm{C}$ garlic; $\triangle,-80^{\circ} \mathrm{C}$ container; $\nabla,-80^{\circ} \mathrm{C}$ garlic; $\square,-196^{\circ} \mathrm{C}$ container; $-196^{\circ} \mathrm{C}$ garlic. 
정 형성구간은 내부에 얼음결정 크기를 결정하는 요소로서 그 시간이 짧을수록 얼음결정의 크기가 작고 고른 분포를 통해 세포 및 조직의 손상을 최소화 할 수 있어 냉동 품질 향상에 영항을 미치는 것으로 알려져 있으며(24), Shin 등 (11)의 냉동 저장중 마늘의 품질 변화에 대한 영향에 대한 연구에서 또한 $-40^{\circ} \mathrm{C}$ 를 이용한 급속 냉동이 가장 좋은 품질 특성을 나타내었다. 따라서 동결속도가 빠른 $-80^{\circ} \mathrm{C}$ 와 -19 $6^{\circ} \mathrm{C}$ 냉동에서 품질 및 생리활성 유지가 뛰어날 것으로 판단 된다.

\section{마늘의 총 페놀 화합물 및 플라보노이드 함량}

페놀 화합물은 식물체의 대표적인 2 차 대사산물로서 단 백질 또는 기타 거대분자와 결합하는 특성을 가지고 있어 항산화 및 항균효과에 관여하는 것으로 알려져 있으며 생리 활성을 평가하는 지표로 사용된다(25). 냉동 조건에 따른 마늘 추출물의 총 페놀 화합물의 농도는 Table 1 에 나타내 었다. 동결보관 없이 제조된 $4^{\circ} \mathrm{C}$ 대조군 추출물에는 총 페놀 화합물 함량이 $6.91 \pm 0.69 \mu \mathrm{g} \mathrm{GAE} / \mathrm{g}$ 였으며, $-20,-80$ 및 -19 $6{ }^{\circ} \mathrm{C}$ 실험군의 추출물에서 총 페놀 화합물은 각각 $6.7 \pm 0.76$, $7.73 \pm 1.07$, 그리고 $7.25 \pm 0.82 \mu \mathrm{g} \mathrm{GAE} / \mathrm{g}$ 으 로 측정되었다. 실험군중 $-80^{\circ} \mathrm{C}$ 와 $-196^{\circ} \mathrm{C}$ 에서 총 페놀 화합물의 함량이 $4^{\circ} \mathrm{C}$ 에 비해 소폭 증가하는 반면 $-20^{\circ} \mathrm{C}$ 는 감소하는 경향을 나타냈으나 분석결과 통계적 유의성을 나타내지 못하였다. Kwon 등(15)의 연구에 따르면 열처리에 의해 마늘 내부 화합물들의 페놀 화합물로의 전환을 촉진하고 추출을 용이 하게 하여 총 페놀 화합물의 함량 증가를 유발한다고 밝히 고 있으나, 본 연구의 냉동처리에 의해서는 유의적인 페놀 화합물의 증가 또는 감소 효과가 일어나지 않는 것으로 나타났다.

플라보노이드는 식물체에서 합성된 페놀 화합물로서 생 리활성을 나타내는 대표적인 물질이다. 냉동 조건에 따른 마늘 추출물의 플라보노이드를 측정한 결과(Table 1)는 다 음과 같다. 플라보노이드 함량은 $4^{\circ} \mathrm{C}$ 대조군 추출물의 경우 $0.327 \pm 0.025 \mu \mathrm{g} \mathrm{QE} / \mathrm{g},-20^{\circ} \mathrm{C}$ 냉동이 $0.263 \pm 0.015 \mathrm{ug} \mathrm{QE} / \mathrm{g}$, $-80^{\circ} \mathrm{C}$ 냉동이 $0.327 \pm 0.058 \mathrm{ug} \mathrm{QE} / \mathrm{g}$, 그리고 $-196^{\circ} \mathrm{C}$ 냉동이

Table 1. The content of total phenolic and flavonoid compounds in each garlic extracts

\begin{tabular}{ccc}
\hline Freezing condition & $\begin{array}{c}\text { Total phenolic content } \\
(\mu \mathrm{g} \mathrm{GAE} / \mathrm{g})\end{array}$ & $\begin{array}{c}\text { Total flavonoid content } \\
\left(\mu \mathrm{g} \mathrm{QE}^{2} / \mathrm{g}\right)\end{array}$ \\
\hline Control $\left(4^{\circ} \mathrm{C}\right)$ & $6.91 \pm 0.69^{\mathrm{a} 3)}$ & $0.327 \pm 0.025^{\mathrm{a}}$ \\
$-20^{\circ} \mathrm{C}$ & $6.70 \pm 0.76^{\mathrm{a}}$ & $0.263 \pm 0.015^{\mathrm{a}}$ \\
$-80^{\circ} \mathrm{C}$ & $7.73 \pm 1.07^{\mathrm{a}}$ & $0.327 \pm 0.058^{\mathrm{a}}$ \\
$-196^{\circ} \mathrm{C}$ & $7.25 \pm 0.82^{\mathrm{a}}$ & $0.260 \pm 0.036^{\mathrm{b}}$ \\
\hline
\end{tabular}

\footnotetext{
${ }^{1)}$ Total phenolic content was expressed as $\mu \mathrm{g} / \mathrm{g}$ gallic acid equivalent.

${ }^{2)}$ Total flavonoid content was expressed $\mu \mathrm{g} / \mathrm{g}$ quercetin equivalent.

${ }^{3)}$ The values represent mean \pm SD for triplicate experiments. Means with same letters within a column are not significantly different at $p<0.05$ by Duncan's multiple range test.
}

$0.260 \pm 0.036 \mathrm{ug} \mathrm{QE} / \mathrm{g}$ 으로서 냉동에 따라 플라보노이드 함 량이 소폭 변화를 나타내었고 그 증감 범위는 관행 냉동법 인 $-20^{\circ} \mathrm{C}$ 에서 가장 높게 나타났다. 이와 같은 결과는 Shin 등(2)의 연구에서 $-40^{\circ} \mathrm{C}$ 냉동저장보다 $-18^{\circ} \mathrm{C}$ 냉동저장에서 향기 성분의 증감 폭이 크다는 보고와 유사한 결과를 나타 내었다. 따라서 플라보노이드가 가지는 소염, 항균, 항바이 러스와 같은 중요한 생리활성 효능(26)은 저온급속냉동을 통해 조금 더 안정적인 유지가 가능할 것으로 예상된다.

\section{DPPH radical 소거능}

라디칼은 생체성분의 산화를 유도하여 노화 및 질병을 유발한다고 알려져 있는 물질로서 이에 대한 제거능 분석은 화학적으로 유도된 DPPH 라디칼에 대한 전자공여 작용을 통한 탈색반응 측정을 통해 판단하며(27), 냉동 조건에 따른 마늘 추출물의 전자공여능을 분석한 결과를 Fig. 2 에 나타 내었다. 추출물의 농도에 따른 흡광도 변화 측정 결과 8 $\mathrm{mg} / \mathrm{mL}$ 에서 약 $94 \%, 4 \mathrm{mg} / \mathrm{mL}$ 에서 약 $84 \%$ 가량으로 유사하 였고, $2 \mathrm{mg} / \mathrm{mL}$ 의 추출물에서는 $4^{\circ} \mathrm{C}$ 와 $-80^{\circ} \mathrm{C}$ 에서 $61 \%$ 로 나타난 것에 비해 $-20^{\circ} \mathrm{C}$ 와 $-196^{\circ} \mathrm{C}$ 에서는 $51 \%$ 가량으로 $10 \%$ 정도 전자공여능이 감소하는 경향을 나타내었다. 이는 플 라보노이드 측정결과(Table 1)의 감소 경향과 일치한다. Chang과 $\operatorname{Kim}(16)$ 및 Jeong 등(28)의 연구에서 열처리에 의한 갈변물질의 형성 유도는 전자공여활성의 증가를 유발 한다고 밝히고 있으며, 이와 같은 사실을 통해 페놀화합물 성분 중 전자공여능을 가지는 물질이 온도 변화에 민감하다 는 것을 예상할 수 있다. 따라서 마늘의 냉동 처리에서는 전자공여 활성을 가지는 물질이 관행냉동법 $\left(-20^{\circ} \mathrm{C}\right)$ 에 비해 $-80^{\circ} \mathrm{C}$ 에서 안정적으로 유지된다고 생각된다.

\section{SOD 유사활성 측정}

$\mathrm{SOD}$ 는 체내의 활성산소를 과산화수소로 전환하여

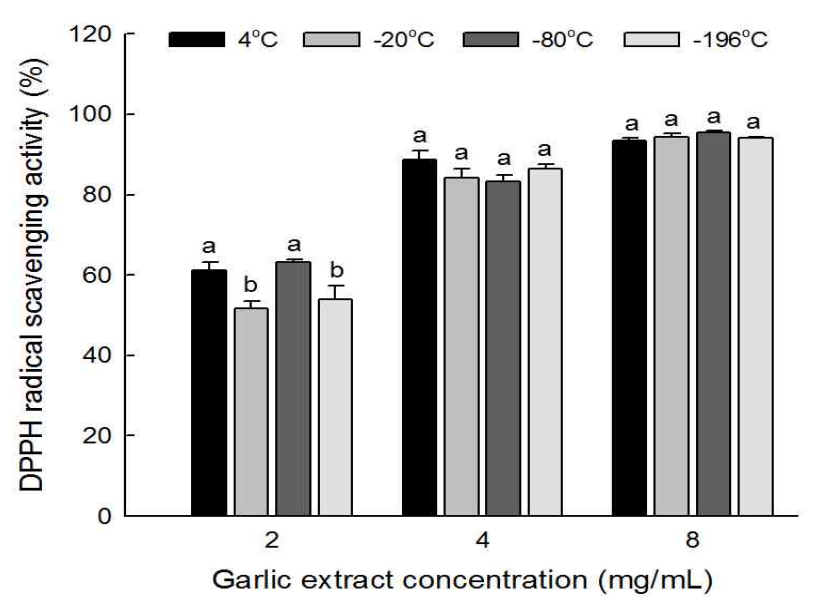

Fig. 2. DPPH radical scavenging activity of garlic extracts according to freezing temperatures.

The values represent the mean \pm SD of triplicate experiments. Means with same letters above a bar are not significantly different at $p<0.05$ by Duncan's multiple range test. 
peroxidase에 의해 제거될 수 있도록 하는 효소로서 항산화 활성의 주요 지표로 사용되며, 마늘 추출물의 SOD 유사활 성 분석 결과는 Fig. 3 과 같다. 양성대조군인 비타민 $\mathrm{C}$ 와 각 실험군의 $\mathrm{SOD}$ 유사활성은 농도가 증가할수록 농도 의 존적인 증가 양상을 나타내었고, 비타민 C $0.023 \mathrm{mg} / \mathrm{mL}$ 이 나타내는 SOD 유사활성은 $41 \%$ 인 것에 반해 마늘 추출물 의 경우 $4.9 \mathrm{mg} / \mathrm{mL}$ 에서 $40 \%$ 가량의 SOD 유사활성을 나타 내었다. 마늘 추출물의 SOD 유사활성은 $4^{\circ} \mathrm{C}$ 대조군에 비해 냉동조건에서 전반적으로 증가 양상을 나타내었으며 $-80^{\circ} \mathrm{C}$ 에서 가장 큰 증가가 확인되었다. 이는 페놀화합물 함량 (Table 1)과 유사한 양상으로 Lee 등(29)의 연구에 따르면 가공 처리에 의해 페놀화합물이 증가함에 따라 SOD 유사 활성이 증가한다는 연구와 일치하는 것으로 마늘의 냉동에 따른 SOD 유사활성의 변화 또한 페놀화합물의 변화에 기 인한다고 생각된다.

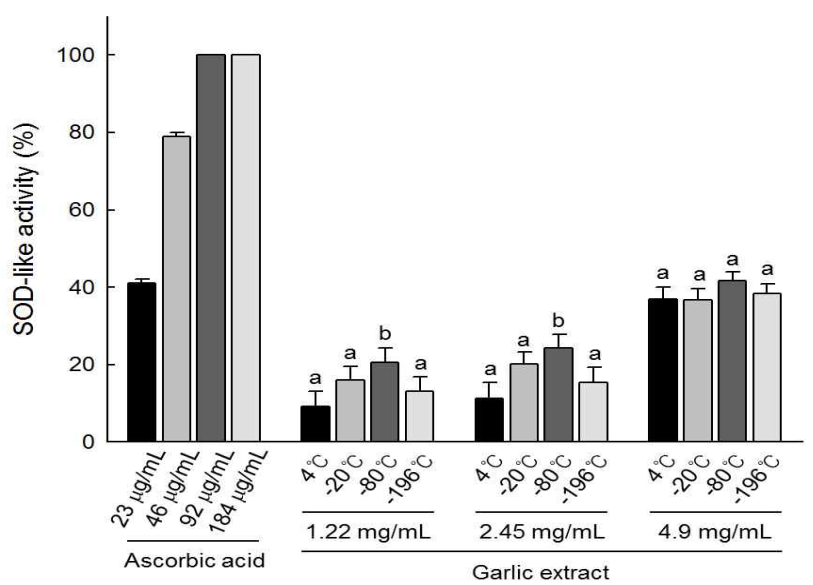

Fig. 3. SOD-like activity of garlic extracts according to freezing temperatures.

The values represent the mean \pm SD of triplicate experiments. Ascorbic acid was used as a positive control. Means with same letters above a bar are not significantly different at $p<0.05$ by Duncan's multiple range test

\section{아질산염 소거능 측정}

체내에서 아질산염은 헤모글로빈에 결합된 철을 산화하 여 메트헤모글로빈을 형성하거나 amine 과 결합하여 발암 물질인 nitrosamine을 형성하여 인체에 유해한 영향을 끼치 기 때문에 이에 대한 제거 능력은 항산화 효과를 측정하는 주요 인자로 사용된다. 냉동 방법을 달리하여 제조한 마늘 추출물의 아질산염 소거능은 Fig. 4 와 같다. 각 실험군의 $\mathrm{pH}$ 를 달리하여 실험한 결과, 일반적으로 낮은 $\mathrm{pH}$ 에서 높은 활성을 나타내었으며, 양성 대조군인 비타민 C $80 \mu \mathrm{g} / \mathrm{mL}$ 의 아질산염 소거능은 $\mathrm{pH} 1.2$ 에서 $26 \%, \mathrm{pH} 3.0$ 에서 $13 \%$ 를 나타내었으며, 마늘 추출물 $8.3 \mathrm{mg} / \mathrm{mL}$ 의 경우 $\mathrm{pH} 1.2$ 에서 $100 \%, \mathrm{pH} 3.0$ 에서 $24 \%$ 가량의 아질산염 소거능을 나타내었 다. $\mathrm{pH}$ 6.0에서는 마늘 추출물 뿐만 아니라 양성대조군인 비타민 C 역시 대부분 활성을 상실하여 $1 \%$ 가량의 아질산
염 소거능을 나타내었으며, 이는 Kang 등(30)의 연구와 일 치하는 것으로 아질산염과 amine 류가 반응하여 nitrosamine 을 형성하는 반응이 낮은 $\mathrm{pH}$ 에서 활발히 일어나는 것이라 고 밝히고 있다. 하지만 마늘의 냉동 조건에 따라서는 유의 적 차이를 확인할 수 없었으며, 아질산염 소거능에 큰 영향 을 미치지 않는 것으로 생각된다.

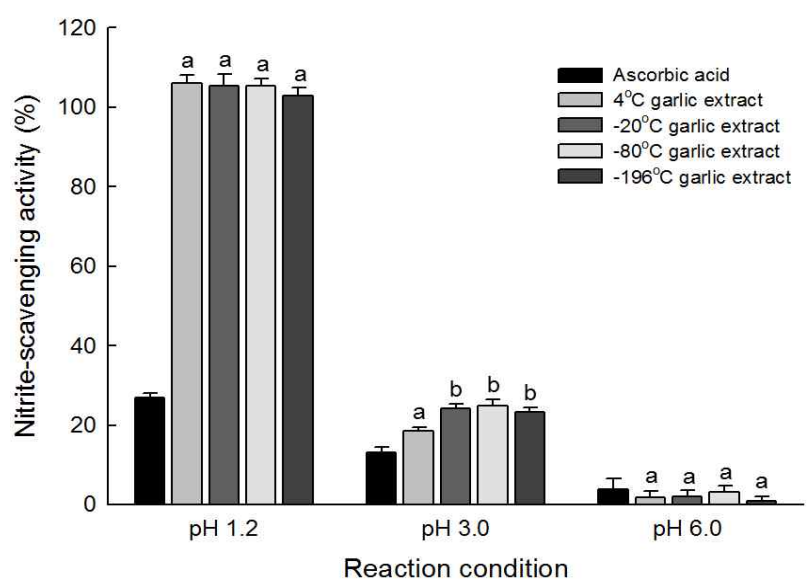

Fig. 4. Nitrite-scavenging activity of garlic extracts according to freezing temperatures.

In this assay, $80 \mu \mathrm{g} / \mathrm{mL}$ ascorbic acid was used as a positive control, and $8.3 \mathrm{mg} / \mathrm{mL}$ garlic extracts were submitted to analysis. The values represent the mean $\pm \mathrm{SD}$ of triplicate experiments. Means with same letters above a bar are not significantly different at $\mathrm{p}<0.05$ by Duncan's multiple range test.

\section{Reducing power}

환원력은 항산화 활성 중 활성산소 종에 전하를 공여하 는 능력으로서 ferric-ferricyanide $\left(\mathrm{Fe}^{3+}\right)$ 를 ferrous $\left(\mathrm{Fe}^{2+}\right)$ 로 환 원시키는 능력을 측정한 것으로 마늘 추출물의 환원력 분석 결과는 Fig. 5 와 같다. 마늘 추출물 $8.3 \mathrm{mg} / \mathrm{mL}$ 의 환원력은

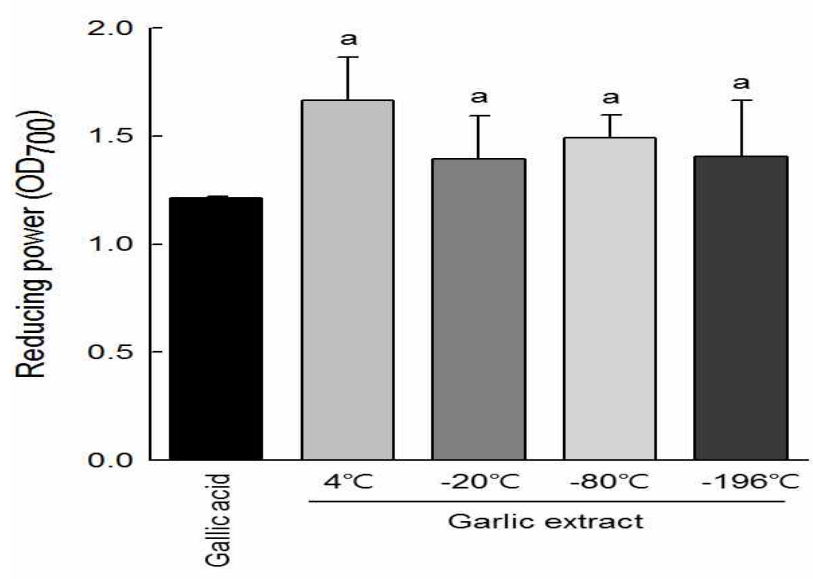

Fig. 5. Reducing power of garlic extracts according to freezing temperatures.

In this assay, $8 \mu \mathrm{g} / \mathrm{mL}$ gallic acid was used as a positive control, and $8.3 \mathrm{mg} / \mathrm{mL}$ garlic extracts were submitted to analysis. The values represent the mean $\pm \mathrm{SD}$ of triplicate experiments. Means with same letters above a bar are not significantly different at $\mathrm{p}<0.05$ by Duncan's multiple range test. 
$1.6 \pm 0.2 \mathrm{abs}$ 수준으로 양성대조구인 gallic acid $8 \mu \mathrm{g} / \mathrm{mL}$ 의 환원력 $1.2 \pm 0.1 \mathrm{abs}$ 보다 약간 높은 활성을 나타내었다. 냉 동 조건에 따른 마늘 추출물의 환원력 비교에서는 $-20^{\circ} \mathrm{C}$ 추출물이 $1.39 \pm 0.2 \mathrm{abs},-80^{\circ} \mathrm{C}$ 추출물이 $1.49 \pm 0.1 \mathrm{abs},-196^{\circ} \mathrm{C}$ 추출물에서 $1.4 \pm 0.3 \mathrm{abs}$ 로 $4^{\circ} \mathrm{C}$ 마늘 추출물의 환원력에 비해 소폭 감소를 나타냈으나 아질산염 소거능(Fig. 4)과 마찬가 지로 유의적인 차이를 나타내지 않았다.

\section{항균활성}

냉동 조건에 따른 마늘 추출물의 Gram(-)균인 E. coli, S. typhimurium, V. vulnificus와 Gram(+)균인 $S$. aureus, $B$. cereus에 대한 항균활성을 측정한 결과는 Table 2 에 나타내 었다. 마늘 추출물 $1.8 \mathrm{mg}$ 에서 패혈증의 원인 균으로 알려 진 V. vulnificus에 대해서 억제환의 크기가 $23.12 \pm 0.13 \mathrm{~mm}$ 로 억제효과가 매우 뚜렷하게 나타났으며, 식중독 원인 균 인 E. coli, S. typhimurium, S. aureus 와 B. cereus에 대해서는 각각 $12.23 \pm 0.79,14.01 . \pm 0.49,15.83 \pm 0.11$ 및 $13.1 \pm 0.01 \mathrm{~mm}$ 로 $V$. vulnificus에 비해서는 낮지만 뚜렷하게 나타났다. 냉 동 조건에 따른 추출물의 항균활성 비교에서는 각 실험군 간의 유의적 차이가 나타나지 않는 것으로 보아 냉동 조건 이 마늘의 항균활성에는 미치는 영향은 미미한 것으로 생각 된다.
$2 \mathrm{mg} / \mathrm{mL}$ 의 추출물에서 $4^{\circ} \mathrm{C}$ 와 $-80^{\circ} \mathrm{C}$ 에서 $61 \%$ 로 나타난 것 에 비해 $-20^{\circ} \mathrm{C}$ 와 $-196^{\circ} \mathrm{C}$ 에서는 $51 \%$ 가량으로 $10 \%$ 정도 라디 칼 소거능이 감소하는 경향을 나타내었고, 마늘 추출물의 $\mathrm{SOD}$ 유사활성은 $4^{\circ} \mathrm{C}$ 대조군에 비해 냉동조건에서 전반적 으로 증가 경향을 나타냈다. 아질산염 소거능은 $\mathrm{pH} 3.0$ 조건 에서 $18 \%$ 수준에서 소폭 증가가 나타난 반면 환원력 비교 에서는 $700 \mathrm{~nm}$ 의 흡광도가 $1.6 \mathrm{abs}$ 수준에서 냉동조건에 따라 감소하는 경향을 나타내었고 $-80^{\circ} \mathrm{C}$ 에서 감소폭이 가 장 적게 나타났으나 유의적인 수준은 못 되었다. 항균활성 비교 실험에서는 마늘 추출물이 E. coli, S. typhimurium, $V$. vulnificus, $S$. aureus와 B. cereus에 대해 높은 항균활성을 나타냈으며, 마늘의 냉동 조건에 따라서는 유의적 차이를 보이지 않았다. 이상의 결과를 종합하여 볼 때 마늘의 냉동 후 추출물의 생리활성은 실험조건에 따른 변화 폭이 크지는 않지만 페놀 화합물과 플라보노이드 및 이에 의한 항산화 및 항균 활성이 안정적으로 유지되는 최적 온도는 $-80^{\circ} \mathrm{C}$ 로 서, 마늘의 냉동 저장 중 품질특성 뿐만 아니라 생리활성기 능 유지라는 두 가지 측면에서 $-20^{\circ} \mathrm{C}$ 관행 냉동보다는 저온 급속냉동이 필요하다고 판단된다.

Table 2. Comparison of antimicrobial activity of the garlic extract with freezing temperatures

$(\mathrm{mm})$

\begin{tabular}{|c|c|c|c|c|c|}
\hline \multirow{2}{*}{ Freezing condition } & \multicolumn{3}{|c|}{ Gram (-) } & \multicolumn{2}{|c|}{ Gram $(+)$} \\
\hline & Escherichia coli & Salmonella typhimurium & Vibrio vulnificus & Staphylococcus aureus & Bacillus cereus \\
\hline Control $\left(4^{\circ} \mathrm{C}\right)$ & $12.23 \pm 0.79^{\mathrm{a} 1)}$ & $14.01 \pm 0.49^{\mathrm{a}}$ & $23.12 \pm 0.13^{\mathrm{a}}$ & $15.83 \pm 0.11^{\mathrm{a}}$ & $13.10 \pm 0.01^{\mathrm{b}}$ \\
\hline$-20^{\circ} \mathrm{C}$ & $12.45 \pm 0.81^{\mathrm{a}}$ & $12.45 \pm 0.19^{b}$ & $23.47 \pm 0.49^{\mathrm{a}}$ & $15.22 \pm 0.20^{\mathrm{a}}$ & $12.10 \pm 0.11^{\mathrm{a}}$ \\
\hline$-80^{\circ} \mathrm{C}$ & $11.48 \pm 0.01^{\mathrm{a}}$ & $13.54 \pm 0.42^{\mathrm{a}}$ & $23.61 \pm 0.75^{\mathrm{a}}$ & $15.86 \pm 0.23^{\mathrm{a}}$ & $12.72 \pm 0.20^{\mathrm{b}}$ \\
\hline$-196^{\circ} \mathrm{C}$ & $12.09 \pm 0.47^{\mathrm{a}}$ & $13.48 \pm 0.72^{\mathrm{a}}$ & $23.34 \pm 0.35^{\mathrm{a}}$ & $16.12 \pm 0.85^{\mathrm{a}}$ & $12.79 \pm 0.33^{b}$ \\
\hline
\end{tabular}

${ }^{1}$ The values represent mean \pm SD for triplicate experiments. Means with same letters within a column are not significantly different at $p<0.05$ by Duncan's multiple range test.

\section{요 약}

마늘의 냉동에 따른 생리활성을 변화를 분석함으로서 생리활성 효능이 유지되는 최적의 냉동 온도를 선정하고자 냉동조건에 따른 마늘 추출물의 항산화 및 항균활성을 비교 분석하였다. 마늘 추출물의 페놀 화합물 함량은 $6.91 \pm 0.69$ $\mu \mathrm{g} \mathrm{GAE} / \mathrm{g}$ 으로 냉동 조건( $\left.-20,-80,-196^{\circ} \mathrm{C}\right)$ 에 따라 큰 차이를 보이지 않았으나, 플라보노이드 함량은 $-80^{\circ} \mathrm{C}$ 에서 $0.327 \pm$ $0.058 \mu \mathrm{g} \mathrm{QE} / \mathrm{g}$ 에 반해 $-20^{\circ} \mathrm{C}$ 에서 $0.263 \pm 0.015 \mu \mathrm{g} \mathrm{QE} / \mathrm{g}$ 으로 소폭 감소를 나타내었다. DPPH 라디칼 소거능 분석에서는

\section{감사의 글}

본 연구는 2015년도 농촌진흥청 공동연구사업(과제번 호: PJ00997502) 및 국립농업과학원 박사후 연수과정 지원 사업에 의해 이루어진 것이며, 이에 감사드립니다.

\section{References}

1. Young CJ, Soon KC (2008) Antioxidant activities of domestic garlic (Allium sativum L.) stems from different 
areas. J Korean Soc Food Sci Nutr, 37, 972-978

2. Hye SJ, Chan JJ, Chen KO, Mi YS, Jung LS, Ju SN (2004) Physicochemical and physiological activities of garlic from different area. Korean J Food Nutr, 17, 237-245

3. Rana SV, Pal R, Vaiphei K, Sharma SK, Ola RP (2011) Garlic in health and disease. Nutr Res Rev, 24, 60-71

4. Mozaffari Nejad AS, Shabani S, Bayat M, Hosseini SE (2014) Antibacterial effect of garlic aqueous extract on Staphylococcus aureus in hamburger. Jundishapur J Microbiol, 7, e13134

5. Ruddock PS, Liao M, Foster BC, Lawson L, Arnason JT, Dillon JA (2005) Garlic natural health products exhibit variable constituent levels and antimicrobial activity against Neisseria gonorrhoeae, Staphylococcus aureus and Enterococcus faecalis. Phytother Res, 19, 327-334

6. Banerjee SK, Maulik SK (2002) Effect of garlic on cardiovascular disorders : a review. Nutrition J, 1, 1-14

7. Masjedi F, Gol A, Dabiri S (2013) Preventive effect of garlic (Allium sativum L.) on serum biochemical factors and histopathology of pancreas and liver in streptozotocin induced diabetic rats. Iran J Pharm Res, 12, 325-338

8. Qidwai W, Ashfaq T (2013) Role of garlic usage in cardiovascular disease prevention: an evidence-based approach. Evid-based Compl Alt, 2013, 1-10

9. Pyo HK, Lee BY (1973) A Physiological and ecological study on the postharvest garlics. J Korean Soc Hort Sci, 14, 25-30

10. Park YH, Park SJ, Han GJ, Choe JS, Lee JY, Kang MS (2012) Quality characteristics of pre-processed garlic during storage according to storage temperature. J Korean Soc Food Sci Nutr, 41, 9941001

11. Shin DB, Lee YC, Kim JH (2000) Changes in quality of garlic during frozen storage. Korean J Food Sci Technol, 32, 102-110

12. Kim JS, Chun HH, Park SH, Choi DS, Choi SR, Oh SS, Yoo SM (2014) System design and performance analysis of a quick freezer using supercooling. J Biosystems Eng, 39, 330-335

13. James C, Seignemartin V, James SJ (2009) The freezing and supercooling of garlic (Allium sativum L.). Int $\mathrm{J}$ Refrig, 32, 253-260

14. Lee YR, Woo KS, Hwang IG, Kim HY, Lee SH, Lee JS, Jeong HS (2012) Physicochemical properties and antioxidant activities of garlic (Allium sativum L.) with different heat and pressure preatments. J Korean Soc Food
Sci Nutr, 41, 278-282

15. Kwon OC, Woo KS, Kim DJ, Hong JT, Jeong HS (2006) Physicochemical characteristics of garlic (Allium sativum L.) on the high temperature and pressure treatment. Korean J Food Sci Technol, 38, 331-336

16. Chang YG, Kim JS (2011) Effects of pretreatment and drying methods on the quality and physiological activities of garlic powders. J Korean Soc Food Sci Nutr, 40, 1680-1687

17. Folin O, Denis W (1912) On phosphotungstic phosphomolybdic compounds as a color reagent. J Biological Chem, 12, 239-249

18. Zhishen J, Mengcheng T, Jianming W (1999) The determination of flavonoid contents in mulberry and their scavenging effects on superoxide radicals. Food Chem, 64, 555-559

19. Blois MS (1958) Antioxidant determinations by the use of a stable free radical. Nature, 181, 1199-1200

20. Marklund S, Marklund G (1974) Involvement of the superoxide anion radical in the autoxidation of pyrogallol and a convenient assay for superoxide dismutase. Eur J Biochem, 47, 469-474

21. Kato H, Lee IE, Chuyen NV, Kim SB, Hayase F (1987) Inhibition of nitrosamine formation by nondialyzable melanoidins. Agric Biol Chem, 51, 1333-1338

22. Oyaizu M (1986) Studies on products of browning reaction. Antioxidative activities of products of browning reaction prepared from glucosamine. Jap J Nutr, 44, 307-315

23. Palaksha MN, Ahmed M, Das S (2010) Antibacterial activity of garlic extract on streptomycin-resistant Staphylococcus aureus and Escherichia coli solely and in synergism with streptomycin. J Nat Sci Biol Med, $1,12-15$

24. Kiani H, Sun DW (2011) Water crystallization and its importance to freezing of foods : a review. Trends Food Sci Tech, 22, 407-426

25. Perron NR, Brumaghim JL (2009) A review of the antioxidant mechanisms of polyphenol compounds related to iron binding. Cell Biochem Biophys, 53, 75-100

26. Rapisarda P, Tomaino A, Lo Cascio R, Bonina F, De Pasquale A, Saija A (1999) Antioxidant effectiveness as influenced by phenolic content of fresh orange juices. J Agric Food Chem, 47, 4718-4723

27. Choi Y, Lee SM, Chun J, Lee HB, Lee J (2006) Influence of heat treatment on the antioxidant activities and polyphenolic compounds of Shiitake (Lentinus edodes) 
mushroom. Food Chem, 99, 381-387

28. Jeong JY, Woo KS, Hwang IG, Yoon HS, Lee YR, Jeong HS (2007) Effects of heat treatment and antioxidant activity of aroma on garlic harvested in different cultivation areas. J Korean Soc Food Sci Nutr, 36, $1637-1642$
29. Lee KS, Kim GH, Kim HH, Kim ES, Park HM, Oh MJ (2009) Physiological functionalities of tea thermally processed from Lxeris dentata root. J Korean Soc Food Sci Nutr, 38, 496-501

30. Kang YH, Park YK, Lee GD (1996) The nitrite scavenging and electron donating ability of phenolic compounds. Korean J Food Sci Technol, 28, 232-239 